\title{
Cooperative learning and the use of blogs in Higher Education. An initiative oriented to promote a deeper understanding of social and ethical issues between teacher students
}

\author{
Lidia Daza, Santiago Eizaguirre
}

Department of Sociology. University of Barcelona, Spain.

\begin{abstract}
The objective of this article is to evaluate the promotion of cooperative learning through the use of blogs in several courses of sociology of education oriented towards undergraduate teacher students. Cooperative learning entails that the student interaction is continued and profound, as well as oriented to obtain a major social and ethical deep learning among students. Each group of students have to create a blog with different information useful for the course developing. Students, from the previous knowledge presented in class, have to define the task (objectives, plan, schedule and final product). Accordingly, each group have to self-manage the work to do (participation of each member, planning, revision...). We combine situations in class with teachers and also cooperative learning among students. In this sense, appears the process of shared knowledge towards cooperative learning. Evaluation questionnaires have shown a positive assessment by students. Findings show that their learning is deeper and more social and ethical, but, they pointed out the workload it entails.
\end{abstract}

Keywords: cooperative learning; blogs; innovative project. 


\section{Introduction}

Cooperative learning through the use of blogs, as well as online teaching strategies, may have a major role in the future of teacher's apprenticeship. This centrality is explained in part by the changes in learning conditions promoted by the Internet. A growing literature deals with this issue in recent years (Alvàrez Herrero, 2018; Alventos et al., 2016; Chawinga, 2017; Ifinedo, 2107; Lee \& Bonk, 2016; Molina et al.. 2016; Piña et al., 2016; Shana \& Abulbdehb, 2015).

Online learning is developing rapidly in higher education. Many academics are experimenting with the building of online communities, embedding blogs, social media and wiki tools into their courses as a way of enhancing learning among students and between themselves and their academical environment. Some of literature is focused on the topic of blogs in higher education as a strategy of online learning. Alventos et al (2016) argue that those practice facilitate access to knowledge, promote a more active and reflective participation in the construction of learning, amplify the social experience of learning, and provide evidence on the progress of students that help to reorient the teaching-learning process stimulating critical judgment. However, problems related to the participation of students and the management of edublogs by teachers are also identified. Molina et al. (2016) underline the importance of offering prior and sufficient information about its use in the subject. It can find several researches analysing students' perceptions and motivational aspects of building online learning communities. Ifinedo (2017) shows how perceived selfefficacy, personal outcome expectations, and perceived support for enhancing social ties are pertinent to explain students' acceptance of blog use for learning. Lee and Bonk (2016) study learners' perceived emotional closeness with other learners after using blogs for writing and sharing weekly reflective journals. Students' interactions may be analysed here in terms of the online interactions among them, the numbers of replies that individual learners had posted to and received from others' postings. The findings of Lee and Bonk indicate that, after the use of the blog as a learning tool, peer relationships are noticeably changed at the end of the semester, when compared to that at the beginning. Chawinga (2017), from an educational technology perspective, explores teaching and learning using Twitter and blogs, and shows how they are catalysts for a learner-centred approach to teaching. Piña et al. (2016) highlight that although the blog helps the development of digital skills, it does not guarantee its future use. In this sense they emphasize the importance of combining the blog with reflective writing strategies, with a feedback of formative character and with the use of other social networks. Shana \& Abulbdehb (2015) also argue how blogs may be used as a tool to facilitate deeper learning, through the use of open-ended questionnaires, student journals and reports, and end-of-class e-portfolios. Blogs have the potential to empower and enhance student learning. 


\subsection{Cooperative group-based learning}

One of the main characteristics of cooperative learning is the positive interdependence among different learners with a common objective because the interaction and the contribution of each member of the group is needed. The dynamics to promote cooperative learning are oriented to the responsibility of each person and also the mutual compromise to perseverate in front of difficulties. The decentralized autonomy, by the distribution of roles and tasks, entails major gains in consensus and conflict resolution skills. Students also develop interpersonal relations and social skills as active listening, dialogue and encourage and respect others. Lastly, using 2.0 tools in class has a key value related to digital alphabetization. The use of the digital social network could promote a continuous training process of personal, civic and community process. In this sense, it could be assessed by the perspective of the development of critical digital citizenship.

The latest studies with students enrolled in Early Childhood Education Teacher degree and Elementary School Teacher degree in Andalusia and Bask Country (Spain) (Cabrero \& Marin, 2014), shown that $80 \%$ of students recognize cooperative learning as the best way to learn. But they are less competent to use digital tools as we assume. However, it is also concluded that students are highly motivated to learn about digital tools to using it their future educative practice.

Our innovative teaching group in University of Barcelona (GIDASRES) was created in 2012 and recognized and considered a consolidated innovative group by the Innovative Teaching Program from the UB (RIMDA). The GIDASRES group has developed three projects in different subjects: elaboration and publication of innovative teaching material; using of case study as an innovative teaching tool; and a cooperative students study about an educative real practice. Our overall balance is positive, but we considered that we have to reinforce some points that we try to work with the present innovative project. The experience that we present is about the introduction of an innovative project to reinforce the cooperative learning creating a blog. This project is recognized by RIMDA office of University of Barcelona (2018PID-UB/007). The duration of the project is two consecutive academic years implemented in coordination among different teachers of the same subject in different studies of Education Faculty (Early Childhood Education Teacher degree and Elementary School Teacher degree). At the end of the first academic year (2018-19) we have done an assessment by students and a personal assessment. We have identified points to reinforce and improve for the next year.

\section{Objectives}

The main object of the innovative project is to ask students to create a web blog to promote de cooperative learning and to developing an ethical and social perspective. We try to 
consolidate working methods and required tools in order that students engage with their learning process and develop transversal skills requested by university. This skills are in the different subject programs: a) ethic commitment; b) learning and responsibility skills; c) communicative skills; e) creative and entrepreneurial skills f) team work. The specific objectives are, that the students:

- learn to be respectful and critical of the internet publications.

- create texts in cooperative way and share them on the internet.

- improve their oral and writing communication.

- learn to assess, and value rigorously the tasks of other students.

- develop their proactivity, important for their future teaching task.

- develop team group skills.

- search information on the internet, and be able to filter it critically.

- develop learning skills in digital context in order to construct a critical citizenship.

\section{Innovative project development}

This project is designed to be implemented in two academic years (2018-2019 and 20192020). After the first year we assess and make a reflection about the initial implementation and the student's acceptation. This innovative experience, carried out by 6 teachers, is implemented in a subject of two university degrees (Childhood teacher training and Primary teacher training). The compulsory subject is in the first semester of first year with 6 credits: Sociology of Education: educative, multicultural and social changes. Approximately there are 50 students by group and in each class were more or less 10 groups of 5 students who created a blog with some information in common and some different information.

In order to reach the objectives mentioned above each group of students has to distribute the tasks to do the posts on the blog -they have to summary texts, present investigations, critical analysis of laws, presentation of study cases, presentation of educative real experiences, critical analysis of films, etc...- Some of these activates required an oral presentation in class in order to facilitate peer learning, oral communication skills and co evaluation, among others. Our point is to improve the utility and to approach the professional reality to the students. It is also a source of information for teacher to assess their efficacy in the tasks. It is clear that the continuous assessment is clue in this project and the feedback is required for the good development of student learning. Each teacher 
decided the specific task that all the groups and just one of them has to develop, we think the flexibility is clue for the good development of the project.

\section{Experience assessment}

Because of each group has to create a post and share it, the learning is an active and dynamic process taking into account the different learning styles of students and the different digital skills. The material of all the tasks are public on the blogs and all the class can participate in other blogs throw the comments. Evaluation and co evaluation is used to assess the tasks, particularly the cooperative work.

\section{Results}

Two evaluation processes were proposed during the course in order to know the impact of this innovative experience on student learning. Firstly, a co-evaluation where each group was asked to evaluate three different blogs from the same course at two points in the course (mid-year and end of course). The students were asked to evaluate the quality of the text, the constancy of the entries, the formality, the link between theory and practice and the dynamism as a social network. This evaluation had a formative purpose and it was in group. Secondly, a self-evaluation that each student does at the end of the course, based on ten items about the learning done through the blog. This consisted of a questionnaire survey where students, individually, were asked about the usefulness of the blog for the acquisition of the different skills shown in the table 1. The assess questionnaire has 10 items to evaluate from 1 to 10 , and at the end there are two open questions. The two questionnaires were published on the Moodle platform in order to facilitate their completion as much as possible.The results of the self-evaluation are shown in following table. 
Table 1. Average valuations in the acquisition of training skills. Academic year 2018-19. ${ }^{1}$

\begin{tabular}{lc}
\hline & Mean \\
\hline Linking between theory and practice & $\mathbf{6 , 8}$ \\
Approaching to the content in a responsibility way & $\mathbf{7 , 1}$ \\
Creative and entrepreneurial skills & $\mathbf{7 , 2}$ \\
Writing skills & $\mathbf{6 , 8}$ \\
Reflexion and critical thinking & $\mathbf{7 , 2}$ \\
Proactivity and participating to reach the results & $\mathbf{7 , 6}$ \\
Being respectful and honest with the authorship & $\mathbf{7 , 3}$ \\
Oral exposition of ideas to obtain consensus & $\mathbf{7 , 6}$ \\
Being aware that the publications in internet have & $\mathbf{7 , 0}$ \\
transcendence & \\
Being respectful of another points of view & $\mathbf{7 , 0}$ \\
\hline \multicolumn{1}{c}{ Total mean } & $\mathbf{7 , 2}$ \\
\hline
\end{tabular}

We consider that the answers were globally positive. The improvement of oral skills and the proactivity and participating to reach the expected results have the highest punctuation. The relation between theory and practice is the less punctuated, this topic is always difficult to develop in an academic university class. From two open questions we obtained qualitative valuations about the blog innovative experience. The questions were 'Pros and cons about the innovative experience to create a blog? Which are the relevant contributions of creating a blog in collaboration with another students?

Regarding the cons, most of the student's answers were coincident. Some considerations are about the organization and dedication, some students mention difficulties to meet all together to do the work, or some of them mention the different effort devoted by the different members of the group. Most of them think is a cons when they cannot choose the colleagues of the group. They pointed out the lack of time to transform the academic task in a post to show on a blog. Students also see some problems because they recognise that don't have enough technical knowledge to develop a proper blog, most of them have never created a blog before. Some of the comments of the students have to be in consideration for the next year, they requested more time in class to develop the blog with the teacher

\footnotetext{
${ }^{1} 262$ participants.
} 
guidance and help. And they also pointed out to need some help to develop skills to reach consensus to decide the final drafting of the posts.

The pros could be summarised as this student say: "Being able to write and share about interesting topics for you and for other colleagues". Students are motivated to share their knowledge with colleagues, teachers and other people interested. Most of them say that it project improves their cooperative skills being more efficiently working in group. Finally, they pointed out that the innovative project allows them to see the society in a critical point of view.

This cooperative project is the first they develop at university. In this sense, they recognise that the experience has important impact in the way to think, share the knowledge and convince others. They say it was useful to summary the information and to try to explain thinks thinking on the audience. They define the innovative experience as an activity which allows cooperation and creativity and commit them to the subject during all the semester. Some of them state that the creation of the posts helps them to interiorize the concepts and understand better the material explained in class.

It is important to mention that our objectives are quite optimistic. We think that the project of creating a blog could improve the commitment in their learning and their ethical and social perspective in the tasks. We think we obtain the first part of our objective but not the second. Improve the ethical and social learning required more time and more guidance by teachers. However, most of students consider this project very interesting because they have to share different points of view, task that have never done it before. They recognise that the fact to do a writing that has to publish in internet has a different transcendence Thant a writing just for the class or the teacher. This situation develop auto critical skills. Students also pointed out that they have improve the skills to search relevant information on internet. The project improve their capacity to summarise and structure the information. This project allows to share values, opinions and respect others, and also they had to improve the organisation and planning to reach de commitment with other colleagues of the group and the colleagues of the all class. Being aware to be active on the blogs pushed them to be committed with the tasks, and also allows them to be creative, drawing, searching links, making gadgets, doing good photos or searching it. They say that have discovered which thinks could contribute each member of the group, being aware of their strong and weak points.

With regard to the co-evaluation questionnaire of the blogs of the other groups, it should be noted that the students generally value the work expressed in it very positively. However, students are more critical about the use of different tools offered by a blog, sometimes scarce and little worked. This leads some groups to appreciate that the relationship between theory and practice is sometimes infrequent and has helped little to understand the contents. 
So the feedback between colleagues has helped the teaching team to demonstrate the need for more collaborative work between teachers so that all groups produce what some have already achieved, which is learning to learn by making a stronger link between theory and practice.

\section{Final considerations}

Cooperative learning in framed in a sociocultural context where the 'how' (socially) and the 'where' (internet) of learning have transcendental values. We are aware that we have to go further in this way. Vygotsky (1979) recognised that learning is a social phenomenon and we learn because of the interaction with others. Following Gros (2000) in cooperative learning different members of the group commit to learn all together. The result only appears when the group work with the same objective that have to decide who works, when and in which way. It is important for us to guarantee in the future that all the members of the group have the same commitment and do the same effort avoiding free riders. Although it is difficult, as Zañartu (2011) conclude, to differentiate the time devoted in the work when it is in group. Since now we see that students have divided the tasks and put all together at the end, but now we want to do a further step trying to guarantee the commitment of all the members.

Cooperative learning by internet could be a teaching learning strategy as Johnson (1993) recognized. Students construct their knowledge throw discussions, reflections and decisions. A computer is a tool to develop this task and to share with other colleagues in class. We have to invigorate the knowledge construction of students, especially with the students with more difficulties. The same author recognise that this learning stimulates the individual initiative. Students when take part of the group put their abilities to reach a decision, it stimulates their motivation enriching the productivity. A part from to improve their self-steam and improve their social and ethical values as the solidarity and mutual respectfulness. It is also important for us, to obtain ways to be sure that this learning is useful for their future professional life.

\section{References}

Álvarez Herrero, J. F. (2018). La utilización de un blog personal entre el alumnado universitario como medio generador de aprendizaje reflexivo. In R. (ed. Roig-Vila (Ed.), El compromiso académico y social a través de la investigación e innovación educativas en la Enseñanza Superior (pp. 14-19). Barcelona: Octaedro.

Alventosa, P. M., Valcárcel, J. V., \& Valencia-peris, A. (2015). Los blogs como entornos virtuales de enseñanza y aprendizaje en Educación Superior 1 Blogs as virtual environments for teaching and learning in Higher Education, 26, 15-31. 
Cabero, J.; Marin, V. (2014). Posibilidades educativas de las redes sociales y el trabajo en grupo. Percepciones de los alumnos universitarios. Comunicar, $n^{\circ}$ 42, v. XXI, 2014, Revista Científica de Educomunicación; páginas 165-172

Caldwell, H., \& Heaton, R. (2016). The interdisciplinary use of blogs and online communities in teacher education. International Journal of Information and Learning Technology, 33(3), 142-158. https://doi.org/10.1108/IJILT-01-2016-0006

Chawinga, W. D. (2017). Taking social media to a university classroom: teaching and learning using Twitter and blogs. International Journal of Educational Technology in Higher Education, 14(1). https://doi.org/10.1186/s41239-017-0041-6

Domingo, M., Sánchez, J. A., \& Sancho, J. M. (2014). Researching with Young People: Collaborating and Educating. Comunicar, 42, 157-164. https://doi: 10.3916/C42-201415

Gros, B. (2000). El ordenador invisible. Barcelona: Gedisa.

Ifinedo, P. (2017). Examining students' intention to continue using blogs for learning: Perspectives from technology acceptance, motivational, and social-cognitive frameworks. Computers in Human Behavior, 72, 189-199. https://doi.org/10.1016/j.chb.2016.12.049

Johnson, C. (1993). Aprendizaje Colaborativo, referencia virtual del Instituto Tecnológico de Monterrey, México. http://campus.gda.itesm.mx/cite

Lee, J., \& Bonk, C. J. (2016). Social network analysis of peer relationships and online interactions in a blended class using blogs. Internet and Higher Education, 28, 35-44. https://doi.org/10.1016/j.iheduc.2015.09.001

Lynch, D. (2010). Application of online discussion and cooperative learning strategies to online and blended college courses. College Student Journal, 44(3), 777-784.

Molina, J. P., Valencia, A., \& Gómez, F. (2016). Innovación docente en educación superior: Edublogs, evaluación formativa y aprendizaje colaborativo. Profesorado, 20(2), 432-450.

Pinya, C., Tur, G., \& Rosselló, M. R. (2016). Los blogs en la formación docente inicial. Estudios Pedagógicos (Valdivia), 42(1), 223-233. https://doi.org/10.4067/s071807052016000100014

Shana, Z. A., \& Abulibdehb, E. S. (2015). Engaging students through blogs: Using blogs to boost a course experience. International Journal of Emerging Technologies in Learning, 10(1), 30-38. https://doi.org/10.3991/ijet.v10i1.4240

Vygotsky, L.S. (1979). El desarrollo de los procesos psicológicos superiores. Barcelona: Crítica.

Zañartu Correa, Luz Maria (2011). Aprendizaje colaborativo: una nueva forma de diálogo Interpersonal y en red. Revista digital de educación y nuevas tecnologías. Contexto educativo. Nueva Alejandría Internet. http://contexto-educativo.com.ar/2003/4/nota02.htm 